\title{
A NOVEL NITRO-OXY SUBSTITUTED ANALOGUE OF ROFECOXIB REDUCES HUMAN COLON CANCER CELL GROWTH
}

\section{This is the author's manuscript}

Original Citation:

Availability:

This version is available http://hdl.handle.net/2318/89587

since 2016-07-26T10:35:10Z

Published version:

DOI:10.1007/s11010-011-1094-9

Terms of use:

Open Access

Anyone can freely access the full text of works made available as "Open Access". Works made available under a Creative Commons license can be used according to the terms and conditions of said license. Use of all other works requires consent of the right holder (author or publisher) if not exempted from copyright protection by the applicable law. 


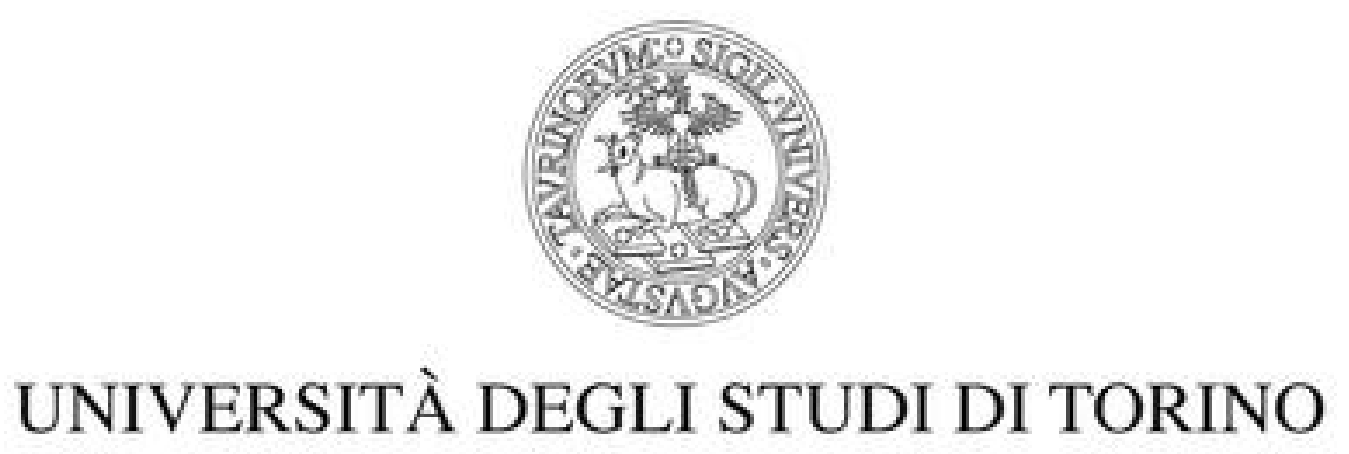

This is an author version of the contribution published on:

Claudia BOCCA, Francesca BOZZO, Monica IEVOLELLA, Antonella MIGLIETTA

A NOVEL NITRO-OXY SUBSTITUTED ANALOGUE OF ROFECOXIB REDUCES HUMAN COLON CANCER CELL GROWTH MOLECULAR AND CELLULAR BIOCHEMISTRY (2012) 361 DOI: $10.1007 / \mathrm{s} 11010-011-1094-9$

The definitive version is available at:

http://www.springerlink.com/index/pdf/10.1007/s11010-011-1094-9 
A NOVEL NITRO-OXY SUBSTITUTED ANALOGUE OF ROFECOXIB REDUCES HUMAN COLON CANCER CELL GROWTH

Claudia BOCCA ${ }^{1}$, Francesca BOZZO, Monica IEVOLELLA, Antonella MIGLIETTA

Department of Experimental Medicine and Oncology - University of Torino - Corso Raffaello, 30 10125 Torino, Italy

\section{${ }^{1}$ CORRESPONDING AUTHOR:}

Department of Experimental Medicine and Oncology - University of Torino

C.so Raffaello, 30

10125 Torino, Italy

Tel: +390116707756

Fax: +390116707753

e-mail: claudia.bocca@unito.it 


\begin{abstract}
Rofecoxib is a specific COX-2 inhibitor able to exert antiproliferative activity against colorectal cancer cells. It was withdrawn from the market after the demonstration of an increased risk of cardiovascular complications after prolonged use. Nevertheless it remains an interesting compound for laboratory research as an experimental COX-2 inhibitor. In the present study the antiproliferative activity of a novel dinitro-oxy-substituted analogue of rofecoxib (NO-rofe), potentially less cardiotoxic, has been investigated in vitro on human colon cancer cells and compared with the action of the parent drug. Due to the fact that COX-2 inhibition is the main characteristic of coxibs we performed all experiments in COX-2-overexpressing (HT-29) and COX2-negative (SW-480) human colon cancer cells, in order to elucidate whether the observed effects were dependent on COX-2 inhibition. Moreover, experiments were performed in order to evaluate whether COX-2 pharmacological inhibition may affect beta-catenin/E-cadherin signalling pathway. NO-rofe exerted a significant antiproliferative activity on COX-2 positive HT-29 human colon cancer cells, being less effective on the COX-2 negative SW-480 human colon cancer cell line. In particular, the rofecoxib analogue retained similar potencies with respect to COX-2 inhibition but was much more active than rofecoxib in inhibiting the growth of human colon cancer cells in vitro. In addition, this novel compound resulted in the induction of membrane $\beta$-catenin/E-cadherin expression, a feature that may significantly contribute to its antiproliferative activity.
\end{abstract}

KEYWORDS: colon cancer cells, NO-rofecoxib, COX-2 


\section{INTRODUCTION}

Epidemiological, animal and cell culture studies have shown chemopreventive and tumor-regressive effects of nonsteroidal anti-inflammatory drugs (NSAIDs) on colorectal cancer [1]. A large body of evidence indicate that regular use of NSAIDs reduces the relative risk of developing colorectal cancer [2], leading to regression of pre-existing adenomas in patients with familial adenomatous polyposis and preventing recurrence of sporadic colonic adenomas [3,4]. However, the prolonged use of NSAIDs is associated with side effects such as gastritis, peptic ulcer, gastrointestinal bleeding, and/or perforation of gastroduodenal ulcers [5]. The anti-inflammatory and antitumor effects of NSAIDs have been, at least partially, attributed to the inhibition of the inducible cyclooxygenase (COX)-2, while unwanted side effects of these drugs arise from the inhibition of the constitutive COX-1 [6]. Deregulation of the COX-2 pathway appears to affect tumorigenesis via a number of distinct mechanisms: promoting tumour maintenance and progression, favoring metastatic spread, and perhaps even participating in tumour initiation [7]. As such, COX-2-selective inhibitors typified by rofecoxib, celecoxib and valdecoxib [8] were developed to reduce the incidence of gastrointestinal side effects associated with non-selective long-term inhibition of COX-1 and COX2 by traditional NSAIDs.

Unfortunately, randomised clinical trials and observational studies have shown an increased risk of myocardial infarction, stroke, hypertension and heart failure during prolonged treatment of patients with highly selective COX-2 inhibitors $[9,10]$. The mechanisms underlying the cardiotoxicity of Coxibs remain a matter of active debate. It has been reported that preferential inhibition of COX-2 in the vasculature, which might lead to an imbalance in the levels of prostacyclin and thromboxane in favor of thrombogenic tromboxane, could contribute to the pro-thrombotic effects of selective COX-2 inhibitors [11].

As a consequence, rofecoxib, as well as other Coxibs, was withdrawn from the market because of increased risk of adverse cardiovascular events and metabolic complications [10]. Although rofecoxib has at present no therapeutic application because of toxicity concerns, nevertheless it remains an interesting and relevant model drug for the synthesis of COX-2 selective inhibitors. Along these lines, a strategy to reduce cardiotoxicity of Coxibs and to improve their benefit-risk profiles may result in the design of a multi-target drug able to combine COX-2 selective inhibition with nitric oxide (NO)-dependent activities. This, in view of the fact that NO is a key regulator of blood flow and an important modulator of platelet and leukocyte activation, adhesion and aggregation [12]. Inhibition of NO synthesis leads to an increase in systemic blood pressure (BP), underscoring the importance of vascular NO generation in controlling BP. A growing number of evidence indicates that NO signalling is a key factor in counteracting the onset and development of 
several cardiovascular diseases including hypertension, myocardial infarction and stroke. NO also prevents atherogenesis by inhibiting vascular smooth muscle cell proliferation and preventing lowdensity lipoprotein oxidation and macrophage activation [13].

NO-donor coxibs have been developed in order to both implement gastric tolerance and to reduce cardiotoxicity of the parent drug and examples of such an approach for drug design have already been reported [14-16].

To this class of compounds belongs a new analogue of rofecoxib (NO-rofe), that has been obtained by introducing two nitro-oxy functions on the phenyl ring, and that has been reported to inhibit COX-2 isoform and to dilate rat aorta strips pre-contracted with phenylephrine [17].

In this study we describe a preliminary biological characterization of the anti-proliferative activity of a new NO-donor and COX-2 inhibitor (NO-rofe). In order to address this specific issue we compared the anti-proliferative activity of rofecoxib and NO-rofe on human colon cancer cells either overexpressing (HT-29) or non expressing (SW-480) COX-2 activity.

\section{MATERIALS AND METHODS}

Materials and reagents

Rofecoxib was obtained from LC Laboratories (Woburn, MA, USA), whereas nitro-oxy analogue of rofecoxib (NO-rofe) was designed and synthesized at the Department of Scienza e Tecnologia del Farmaco, University of Torino, Italy (Fig. 1) [17]. The drugs were solubilized in dimethylsulfoxide (DMSO) (Sigma Chemical) and freshly diluted in culture medium before each experiment. The final DMSO concentration never exceeded $0.1 \%$ and this condition was used as control in each experiment.

Rabbit polyclonal antibodies raised against c-myc and ERK1, mouse monoclonal antibody raised against E-cadherin, $\beta$-catenin and phospho-ERK1/2 as well as goat anti-rabbit and goat anti-mouse secondary antibodies were obtained from Santa Cruz Biotechnology Inc. (CA, USA). Rabbit polyclonal antibody raised against COX-2 and COX-2 purified protein was from Cayman Chemical (Michigan, USA). Enhanced chemiluminescence (ECL) detection system was from Amersham Pharmacia Biotech (Uppsala, Sweden). All other reagents were purchased from Sigma Chemical Co. (St. Louis, MO).

\section{Cell line and culture conditions}

The human HT-29 and SW-480 colon cancer cell lines were obtained from American Type Cell Culture (Manassas, VA, USA) and were grown and amplified at $37{ }^{\circ} \mathrm{C}$ in a humidified $5 \% \mathrm{CO}_{2}$ 
environment in McCOY'S 5A (HT-29) and DMEM (SW-480) medium supplemented with 10\% foetal bovine serum, $100 \mathrm{U} / \mathrm{ml}$ penicillin, $100 \mu \mathrm{g} / \mathrm{ml}$ streptomycin and $25 \mu \mathrm{g} / \mathrm{ml}$ amphotericin B. For the experiments, cells were seeded at a density of $3 \times 10^{4}$ cells $/ \mathrm{cm}^{2}$ and cultured for $24 \mathrm{~h}$ to allow them to adhere to the substratum and then treated with either test compounds or DMSO.

\section{Viability assay}

Cells were seeded in 12-well culture plates and properly treated. Aliquots of cell suspension were incubated with trypan blue solution $(0.5 \%$ in $\mathrm{NaCl})$ for $5 \mathrm{~min}$ to assess cell viability. Finally, cells were transferred to the Bürker chamber and counted by light microscope. Dead cells were defined as those stained with the dye. $\mathrm{IC}_{50}$ values (concentration that caused $50 \%$ inhibition of growth) were calculated from a graph using SigmaPlot software.

\section{Total extracts}

Cells were seeded in $75 \mathrm{~cm}^{2}$ plates and properly treated. Cells were suspended in lysis buffer containing $20 \mathrm{mM}$ Tris- $\mathrm{HCl}(\mathrm{pH} 7.4), 150 \mathrm{mM} \mathrm{NaCl}, 5 \mathrm{mM}$ ethylenediaminetetraacetic acid (EDTA), $0.1 \mathrm{mM}$ phenylmethyl-sulfonyl fluoride (PMSF), $0.05 \%$ aprotinin, $0.1 \%$ igepal and then incubated for $30 \mathrm{~min}$ at $4{ }^{\circ} \mathrm{C}$. The suspension was centrifuged for $25 \mathrm{~min}$ at $12,000 \mathrm{rpm}$ and the supernatant from this centrifugation was saved as the total extracts.

\section{Membrane-associated fractions}

Cells were seeded in $75 \mathrm{~cm}^{2}$ plates and properly treated. Cells were suspended in hypotonic buffer containing $10 \mathrm{mM}$ Tris ( $\mathrm{pH} 7.4$ ), $0.2 \mathrm{mM} \mathrm{MgCl}_{2}, 2 \mu \mathrm{g} / \mathrm{ml}$ pepstatin A, $2 \mu \mathrm{g} / \mathrm{ml}$ leupeptin and $100 \mu \mathrm{g} / \mathrm{ml} \mathrm{PMSF}$ for $10 \mathrm{~min}$ on ice and then homogenized with a Dounce homogenizer. The homogenates were centrifuged for $37 \mathrm{~min}$ at $20,750 \mathrm{rpm}$; the resulting precipitate was analysed as the membrane-associated fraction.

\section{Western blot analysis}

Protein content was evaluated using the Protein Assay Kit 2 (Bio-Rad Laboratory, Hercules, CA). Equal amounts of proteins $(50 \mu \mathrm{g})$ were mixed with solubilization buffer containing $250 \mathrm{mM}$ Tris (pH 8.8), 4\% sodium dodecyl sulfate (SDS), $16 \%$ glycerol, 8\% 2-mercaptoethanol and $0.1 \%$ bromophenol blue, and then fractionated by electrophoresis on sodium dodecyl sulfate polyacrylamide gel electrophoresis (SDS-PAGE). Proteins were transferred onto nitrocellulose for $2 \mathrm{~h}$ in a Biorad electro-blotting device. Nitrocellulose matrices were blocked with 5\% milk in TBST

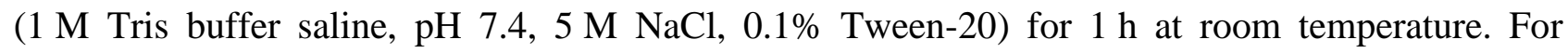
immunodetection, matrices were incubated overnight at $4{ }^{\circ} \mathrm{C}$ with primary antibody. The matrices were then detected by incubation for $1 \mathrm{~h}$ at room temperature with the corresponding horseradish peroxidase-conjugated secondary antibody. The immunoreactive bands were visualized using the ECL system. Band intensities were quantified by densitometry and expression of proteins was 
reported as a proportion of $\beta$-actin or ERK1 protein expression to control for any discrepancies in gel loading. Fold change versus control values has been calculated by normalizing densitometric values obtained from the various proteins with those obtained for $\beta$-actin or ERK1 (VersaDoc Imaging System 3000, Biorad).

\section{Statistical analysis}

Differences between the means were analyzed for significance using the one-way ANOVA test with Bonferroni post hoc multiple comparisons, used to assess the differences between independent groups. All values are expressed as means $\pm \mathrm{SD}$, and differences were considered significant at $p<0.05$.

\section{RESULTS AND DISCUSSION}

As a first experimental approach, we examined the sensitivity of the COX-2 positive (HT-29) and negative (SW-480) colon cancer cell lines to rofecoxib and to its nitro-oxy derivative (NO-rofe).

HT-29 cells were found to be more sensitive to the anti-proliferative effects of the drugs than SW480 cells. Increasing concentrations of NO-rofe decreased dramatically HT-29 cell growth in a time- and dose-dependent manner (figure $1 \mathrm{~B}$ ). The $\mathrm{IC}_{50}$ values (i.e., concentration that produced $50 \%$ inhibition of the growth) for NO-rofe was $35.9 \mu \mathrm{M}$ at $24 \mathrm{~h}, 19.6 \mu \mathrm{M}$ at $48 \mathrm{~h}$ and $9.6 \mu \mathrm{M}$ at 72h. Rofecoxib only marginally affected the growth of HT-29 cells (10-25\% at $50 \mu \mathrm{M})$ (figure 1A), making impossible to calculate $\mathrm{IC}_{50}$ values. It is interesting to note the co-treatment of this cell line with NO-rofe and the NO scavenger carboxy-PTIO (cPTIO) completely reverted the inhibitory effect on cell viability (figure 1C).

Although a slight degree of growth inhibition was observed in SW-480 cells, these cells were barely sensitive to both compounds according to their lack of COX-2 expression (figure 1D).

According to cell viability data, both NO-rofe and, to a lesser extent, rofecoxib resulted in a decreased phosphorylation/activation of ERK1/2 and expression of the transcription factor c-myc only in COX-2-overexpressing HT-29 cells (figure 2A), with no significant effects observed in COX-2-negative SW-480 cells (figure 2B). When HT-29 cells were co-treated with NO-rofe and the NO scavenger this experimental approach did not result in a complete reversion of the effects on ERK1/2 phosphorylation state and c-myc protein levels (figure 2A), supporting the hypothesis that the drugs may down-regulate proliferation by affecting the COX-2 pathway.

The role of COX-2 was then further investigated in order to analyse its involvement in growth inhibition. As expected, in HT-29 cells rofecoxib and NO-rofe down-regulated the expression of intracellular COX-2 protein levels (approx. $45 \%$ inhibition) to a very similar and significant extent 
(figure 2A). According to literature data [18], no significant change in COX-2 protein level was observed in COX-2 negative SW-480 cells (data not shown).

COX-2 activity was also analysed by evaluating prostaglandin $\mathrm{E}_{2}\left(\mathrm{PGE}_{2}\right)$ concentration in HT-29 cells. Both rofecoxib and NO-rofe, employed at $50 \mu \mathrm{M}$ concentration, significantly decreased $\mathrm{PGE}_{2}$ synthesis to no more than $40 \%$ of control values (data not shown).

Along these lines, it is known that $\mathrm{PGE}_{2}$, through the stimulation of EP2 receptor, leads to the inactivation of GSK-3 $\beta$, leading in turn to $\beta$-catenin accumulation in the nucleus and to the increased transcription of its target genes [19]. $\beta$-catenin, which is overexpressed in nearly all colorectal carcinomas, is known to function as a transcription factor involved in oncogenic signal transduction thereby strongly promoting tumor growth and impairing patient survival [20].

Previous studies from our [16] and other laboratories [21] have shown that suppression of $\beta$ catenin-mediated signal transduction represents a major pharmacological mechanism of the COX-2 selective inhibitor celecoxib which is responsible for its chemopreventive effect.

In the present study, in agreement with other literature data [22], we found that rofecoxib exerted only a negligible effect on the membrane expression of $\beta$-catenin and E-cadherin (figure 2A), indicating that the modulation of $\beta$-catenin system may not represent a general effect common to all coxibs.

Whether NO-rofe was concerned, this drug potently induced $\beta$-catenin and E-cadherin membrane expression, increasing the amount of $\beta$-catenin available to form complexes with E-cadherin (figure $2 \mathrm{~A}$ ); of interest, the NO scavenger was able to significantly reduce both of these effects. This finding is potentially relevant since down-regulation of E-cadherin is currently believed to play a role in tumour invasion, which requires the ability of cells to spread to distant sites and is associated with reduced cell-cell adhesion [23]. These results, together with the fact that in SW-480 cells only NO-rofe retains the ability to induce the expression of both $\beta$-catenin and E-cadherin (figure $2 \mathrm{~B}$ ), seem to confirm that COX-2 inhibition may significantly contribute to the anti-proliferative efficacy of this drug while the presence of the nitro-oxy function is more likely involved in the modulation of $\beta$-catenin/E-cadherin system, modulation that appears then as COX-2 independent.

These data are in accordance with results obtained from our previous work, in which we evaluated the biological effects of a novel nitro-oxy derivative of celecoxib in human colon cancer cells with the aim to elucidate whether these properties may depend on COX-2 inhibition and/or NO-release. The overall final results from this study indicated that the nitro-oxy derivative behaved like celecoxib in terms of COX-2 inhibition, while the benzyl nitrate had no such effects; on the contrary, the $\beta$-catenin system was activated by the nitro-oxy derivative as well as by benzyl nitrate 
alone more potently than the parent compound celecoxib, suggesting a possible regulatory role for NO [24].

\section{CONCLUSIONS}

Our preliminary results suggest that NO-rofe can display its activity through both COX-2 inhibition and NO-donating property. This compound retains similar potencies with respect to COX-2 activity inhibition but is much more active than rofecoxib in inhibiting the growth of human colon cancer cells in vitro. In addition, the strong induction of membrane $\beta$-catenin/E-cadherin expression may represent an important contributing factor to the antitumor activity of this selective COX-2 inhibitor. As a matter of fact, overexpression of membrane E-cadherin and $\beta$-catenin caused by NOrofe could negatively affect cell migration and tumour invasiveness, as already shown for other COX-2 inhibitors [25].

Further experimental work is needed in order to fully outline the molecular mechanisms responsible for the antiproliferative effect exerted by NO-rofe in order to support its use for treatment or chemoprevention of colon cancer. 


\section{Acknowledgement}

Financial support was from Regione Piemonte and University of Torino.

\section{REFERENCES}

1. Reddy BS, Rao CV (2002) Novel approaches for colon cancer prevention by cyclooxygenase-2 inhibitors, J Environ Pathol Toxicol Oncol 21:155-164.

2. Rostom A, Dube C, Lewin G, Tsertsvadze A, Barrowman N, Code C, Sampson M, Moher D (2007) Nonsteroidal anti-inflammatory drugs and cyclooxygenase-2 inhibitors for primary prevention of colorectal cancer: a systematic review prepared for the U.S. Preventive Services Task Force, Ann Intern Med 146:376-389.

3. Arber N, Eagle CJ, Spicak J, Rácz I, Dite P, Hajer J, Zavoral M, Lechuga MJ, Gerletti P, Tang J, Rosenstein RB, Macdonald K, Bhadra P, Fowler R, Wittes J, Zauber AG, Solomon SD, Levin B (2006) Celecoxib for the prevention of colorectal adenomatous polyps, N Engl J Med 355:885-895.

4. Bertagnolli MM, Eagle CJ, Zauber AG, Redston M, Solomon SD, Kim K, Tang J, Rosenstein RB, Wittes J, Corle D, Hess TM, Woloj GM, Boisserie F, Anderson WF, Viner JL, Bagheri D, Burn J, Chung DC, Dewar T, Foley TR, Hoffman N, Macrae F, Pruitt RE, Saltzman JR, Salzberg B, Sylwestrowicz T, Gordon GB, Hawk ET (2006) Celecoxib for the prevention of sporadic colorectal adenomas, N Engl J Med 355:873-884.

5. Bombardier C, Laine L, Reicin A, Shapiro D, Burgos-Vargas R, Davis B, Day R, Ferraz MB, Hawkey CJ, Hochberg MC, Kvien TK, Schnitzer TJ (2000) Comparison of upper gastrointestinal toxicity of rofecoxib and naproxen in patients with rheumatoid arthritis: VIGOR Study Group, N Engl J Med 343:1520-528.

6. Vane JR, Bakhle YS, Botting RM (1998) Cyclooxygenases 1 and 2, Annu Rev Pharmacol Toxicol 38:97-120.

7. Greenhough A, Smartt HJ, Moore AE, Roberts HR, Williams AC, Paraskeva C, Kaidi A (2009) The COX-2/PGE2 pathway: key roles in the hallmarks of cancer and adaptation to the tumour microenvironment, Carcinogenesis 30:377-386.

8. De Leval X, Julemont F, Benoit V, Frederich M, Pirotte B, Dogne JM (2004) First and second generations of COX-2 selective inhibitors, Minirev Med Chem 4:597-601. 
9. Baron JA, Sandler RS, Bresalier RS, Lanas A, Morton DG, Riddell R, Iverson ER, Demets DL (2008) Cardiovascular events associated with rofecoxib: final analysis of the APPROVe trial, Lancet 372:1756-1764.

10. Solomon SD, McMurray JJ, Pfeffer MA, Wittes J, Fowler R, Finn P, Anderson WF, Zauber A, Hawk E, Bertagnolli M (2005) Cardiovascular risk associated with celecoxib in a clinical trial for colorectal adenoma prevention, N Engl J Med 352: 1071-1080.

11. Grosser T, Fries S, FitzGerald GA (2006) Biological basis for the cardiovascular consequences of COX-2 inhibition: therapeutic challenges and opportunities, J Clin Invest 116:4-15.

12. Huerta S, Chilka S, Bonavida B (2008) Nitric oxide donors: novel cancer therapeutics, Int J Oncol 33:909-27.

13. Naseem KM (2005) The role of nitric oxide in cardiovascular diseases, Mol Aspects Med 26:33-65.

14. Ranatunge RR, Augustyniak M, Bandarage UK, Earl RA, Ellis JL, Garvey DS, Janero DR, Letts LG, Martino AM, Murty MG, Richardson SK, Schroeder JD, Shumway MJ, Tam SW, Trocha AM, Young DV (2004) Synthesis and selective cyclooxygenase-2 inhibitory activity of a series of novel, nitric oxide donor-containing pyrazoles, J Med Chem 47:2180-2193.

15. Chegaev K, Lazzarato L, Tosco P, Cena C, Marini E, Rolando B, Carrupt PA, Fruttero R, Gasco A (2007) NO-donor COX-2 inhibitors. New nitrooxy-substituted 1,5diarylimidazoles endowed with COX-2 inhibitory and vasodilator properties, J Med Chem 50:1449-1457.

16. Bozzo F, Bassignana A, Lazzarato L, Boschi D, Gasco A, Bocca C, Miglietta A (2009) Novel nitro-oxy derivatives of celecoxib for the regulation of colon cancer cell growth, Chem Biol Interact 182:183-90.

17. Boschi D, Cena C, Di Stilo A, Rolando B, Manzini P, Fruttero R, Gasco A (2010) Nitrooxymethyl-substituted analogues of rofecoxib: synthesis and pharmacological characterization, Chem Biodivers 7:1173-1182.

18. Smith ML, Hawcroft G, Hull MA (2000) The effect of non-steroidal anti-inflammatory drugs on human colorectal cancer cells: evidence of different mechanisms of action, Eur $\mathbf{J}$ Cancer 36:664-674

19. Castellone MD, Teramoto H, Williams BO, Druey KM, Gutkind JS (2005) Prostaglandin E2 promotes colon cancer cell growth through a Gs-axin-beta-catenin signaling axis, Science 310:1504-1510. 
20. Buhmeida A, Elzagheid A, Algars A, Collan Y, Syrjänen K, Pyrhönen S (2008) Expression of the cell-cell adhesion molecule beta-catenin in colorectal carcinomas and their metastases, APMIS 116:1-9.

21. Tuynman JB, Vermeulen L, Boon EM, Kemper K, Zwinderman AH, Peppelenbosch MP, Richel DJ (2008) Cyclooxygenase-2 inhibition inhibits c-Met kinase activity and Wnt activity in colon cancer, Cancer Res 68:1213-1220.

22. Gardner SH, Hawcroft G, Hull MA (2004) Effect of nonsteroidal anti-inflammatory drugs on beta-catenin protein levels and catenin-related transcription in human colorectal cancer cells, Br J Cancer 91:153-63.

23. Cavallaro U, Christofori G (2004) Cell adhesion and signalling by cadherins and Ig-CAMs in cancer, Nat Rev Cancer 4:118-132.

24. Bocca C, Bozzo F, Bassignana A, Miglietta A (2010) Antiproliferative effect of a novel nitro-oxy derivative of celecoxib in human colon cancer cells: role of COX-2 and nitric oxide, Anticancer Res 30:2659-66.

25. Noda M, Tatsumi Y, Tomizawa M, Takama T, Mitsufuji S, Sugihara H, Kashima K, Hattori T (2002) Effects of etodolac, a selective cyclooxygenase-2 inhibitor, on the expression of E-cadherin-catenin complexes in gastrointestinal cell lines, J Gastroenterol 37:896-904. 


\section{FIGURE LEGENDS}

Figure 1. Molecular structure of rofecoxib (PM: 315.35 uma) and its nitro-oxy derivative (PM: 386.32 uma).

Figure 2. Effect of rofecoxib and NO-rofe on the growth of COX-2 positive (HT-29) and negative (SW-480) colon cancer cells.

HT-29 cells were exposed for 24,48 and $72 \mathrm{~h}$ to different concentrations of rofecoxib (A) and NOrofe (B). Untreated cells incubated in the presence of vehicle (0.1\% DMSO) were used as controls. HT-29 (C) and SW-480 (D) cells were exposed for $24 \mathrm{~h}$ to 10 and $50 \mu \mathrm{M}$ concentrations of compounds, with or without carboxy-PTIO.

Cell viability was determined by the trypan blue exclusion test and calculated by standardizing viable untreated cells to $100 \%$. The values represent the mean of 3 independent experiments each performed in triplicate (bars, SD). Statistical significance compared with untreated control: $* P<0.05, * * P<0.01, * * * P<0.001$, by one-way ANOVA test with the Bonferroni.

Figure 3. Effect of rofecoxib and NO-rofe on COX-2, pERK, c-myc, $\beta$-catenin and E-cadherin expression in HT-29 and SW-480.

HT-29 (A) and SW-480 (B) cells were exposed for $24 \mathrm{~h}$ to $50 \mu \mathrm{M}$ concentration of the drugs, with or without carboxy-PTIO. Untreated cells incubated in the presence of vehicle $(0.1 \%$ DMSO) were used as controls.

Total lysates were probed with anti-COX-2, anti-pERK and anti-c-myc antibody and normalized with anti-ERK1/2 or anti- $\beta$-actin antibody; COX-2 purified protein was used as positive control. Membrane-associated fractions were probed with anti-E-cadherin and anti- $\beta$-catenin antibody and protein content was routinely stained using Ponceau Red dye.

Protein contents were quantified by densitometry. A representative experiment from at least two independent experiments is shown. 